\title{
A case of isolated adrenocorticotropic hormone deficiency: a rare but possible cause of hypercalcemia
}

This article was published in the following Dove Press journal:

International Medical Case Reports Journal

27 March 2015

Number of times this article has been viewed

\author{
Yumi Harano' \\ Atsuko Kitano \\ Yurika Akiyama' \\ Lisa Kotajima' \\ Kazufumi Honda' \\ Hiroko Arioka' \\ 'Department of General Internal \\ Medicine, ${ }^{2}$ Department of Medical \\ Oncology, St Luke's International \\ Medical Center, Tokyo, Japan
}

Correspondence: Yumi Harano Department of General Internal Medicine, St. Luke's International Medical Center, 9-I Akashi-cho, Chuo-ku, Tokyo 104-8560, Japan

$\mathrm{Tel}+8 \mathrm{I} 355507166$

Fax +8I 355502436

Email yuhar@luke.ac.jp

\begin{abstract}
A 52-year-old woman presented with an 8-month history of epigastric pain, nausea, and weight loss. One year before, she was diagnosed with breast cancer. During the postoperative chemotherapy, she developed epigastric pain and nausea. As a result, she gradually lost $12 \mathrm{~kg}$ of her body weight. We performed upper gastrointestinal endoscopy, which revealed mild erosive gastritis. After the treatment with a proton pump inhibitor, her symptoms persisted. Before the admission, mild hypercalcemia was pointed out. Fluid replacement didn't improve hypercalcemia. We assessed adrenocortical function, which showed that her serum cortisol and adrenocorticotropic hormone were decreased. Through loading tests, we established diagnosis of isolated adrenocorticotropic hormone deficiency. She was treated with hydrocortisone. Soon after the treatment, her serum calcium level returned to normal and her symptoms improved. In a case of hypercalcemia unresponsive to fluid replacement, we recommend ruling out adrenal insufficiency after excluding more common diseases which induce hypercalcemia.
\end{abstract}

Keywords: hypercalcemia, breast cancer, chemotherapy, adrenocorticotropic hormone deficiency, adrenocortical insufficiency

\section{Introduction}

Adrenal insufficiency is defined by the impaired synthesis and release of adrenocortical hormones. It can be caused by diseases of the adrenal gland (primary), interference with adrenocorticotropic hormone (ACTH) secretion by the pituitary gland (secondary), or interference with corticotropin-releasing hormone secretion by the hypothalamus (tertiary). Isolated ACTH deficiency is classified as secondary adrenal insufficiency. In primary adrenocortical insufficiency, $5.5 \%$ of the patients present with hypercalcemia. ${ }^{1}$ The proportion of secondary adrenal insufficiency is unknown. We report a case of isolated ACTH deficiency with hypercalcemia.

\section{Case report}

A 52-year-old Japanese woman presented with an 8-month history of epigastric pain, nausea, and weight loss. One year before, she was diagnosed with right breast cancer, which was resected with breast sparing surgery. She received postoperative chemotherapy using paclitaxel, fluorouracil, epirubicin, and cyclophosphamide. During the chemotherapy, she developed epigastric pain and nausea. As a result, she gradually lost $12 \mathrm{~kg}$ of her body weight over 8 months. Her oncologists consulted our department about her weight loss. At first, we performed upper gastrointestinal endoscopy, suggesting she had mild erosive gastritis. We treated her gastritis with a proton pump inhibitor, but her symptoms persisted. She was admitted because of her progressive dehydration. 
Before the admission, mild hypercalcemia (serum calcium $2.8 \mathrm{mmol} / \mathrm{L}$, normal reference: $2.1-2.5 \mathrm{mmol} / \mathrm{L}$; serum albu$\min 41 \mathrm{~g} / \mathrm{L}$, normal reference: $35-50 \mathrm{~g} / \mathrm{L}$ ) was pointed out by her oncologists. They performed contrast-enhanced computed tomography and whole body bone scintigraphy, and measured thyroid hormones (free T4 $1.32 \mathrm{ng} / \mathrm{dL}$, normal reference: $1.00-1.64 \mathrm{ng} / \mathrm{dL}$; free T3 $4.3 \mathrm{pg} / \mathrm{mL}$, normal reference: 2.3-4.3 pg/mL; TSH $3.52 \mu \mathrm{IU} / \mathrm{mL}$, normal reference: $0.45-$ $4.95 \mu \mathrm{IU} / \mathrm{mL})$, serum 1, 25-dihydroxyvitamin D (8 pg/mL, normal reference: $20-60 \mathrm{pg} / \mathrm{mL})$, intact parathyroid hormone (9 pg/mL, normal reference: $10-65 \mathrm{pg} / \mathrm{mL}$ ), and parathyroidhormone-related protein-C (unmeasurable level, normal reference: less than $1.1 \mathrm{pmol} / \mathrm{L})$. As a result, malignancy including bone metastasis, hyperthyroidism, hyperparathyroidism, vitamin D intoxication, and paraneoplastic syndrome were not detected. At this point, though dehydration was her oncologists' tentative diagnosis, fluid replacement didn't improve hypercalcemia. Considering that the appetite loss was too severe for mild hypercalcemia and the epigastric pain without remarkable endoscopic findings was refractory to the proton pump inhibitor, we suspected endocrine diseases as the cause of her symptoms and assessed adrenocortical function. As a result, her morning serum cortisol $(0.12 \mu \mathrm{g} / \mathrm{dL}$, normal reference: $6.2-19.4 \mu \mathrm{g} / \mathrm{dL})$ and ACTH $(1.2 \mathrm{pg} / \mathrm{mL}$, normal reference: $7.2-63.3 \mathrm{pg} / \mathrm{mL}$ ) were decreased remarkably. The anterior pituitary stimulation test revealed that the ACTH reactivity to corticotropin-releasing hormone was selectively impaired, while the other pituitary hormones were appropriately responded (Table 1). The result of an insulin tolerance test showed similar findings (Table 2). Further investigations revealed that magnetic resonance images showed she had no pituitary tumor (Figure 1) and anti-pituitary antibody was negative. We established a final diagnosis of isolated ACTH deficiency. She was treated with hydrocortisone $15 \mathrm{mg}$ a day. Four days after the treatment, her serum calcium level returned to normal and her symptoms including epigastric pain and nausea improved.

\section{Discussion}

Isolated ACTH deficiency is a rare disorder, classified as secondary adrenocortical insufficiency and has various clinical presentations. ${ }^{2,3}$ Wide varieties of presenting symptoms were reported, including depressive disorder, ${ }^{4}$ lower extremities' motion abnormality, ${ }^{5}$ and stress-induced cardiomyopathy. ${ }^{6,7}$ Compared with primary adrenocortical insufficiency, which has clinical presentations, skin pigmentation, and electrolyte abnormalities including hyponatremia and hyperkalemia, the symptoms and physical findings of secondary adrenocortical insufficiency are nonspecific and difficult to diagnose. Hypercalcemia was reported in $5.5 \%$ of primary adrenocortical insufficiency. The proportion of hypercalcemia is unknown in secondary adrenocortical insufficiency. Though the mechanism of hypercalcemia in adrenocortical insufficiency was unknown in detail, lack of serum cortisol is considered to be related to the increase of calcium reabsorption from renal tubules and release from bone.

We found three case reports about hypercalcemia caused by isolated ACTH deficiency. Grossman et al reported on a 64-year-old woman who presented with a 2-month history of nausea and weight loss. ${ }^{8}$ Her corrected serum calcium level was $3.29 \mathrm{mmol} / \mathrm{L}$ and serum cortisol and ACTH were at abnormally low values. After the administration of hydrocortisone, hypercalcemia was improved. Kato et al reported on a 44-year-old female hemodialysis patient. ${ }^{9}$ Her serum calcium level was elevated to $3.72 \mathrm{mmol} / \mathrm{L}$ for 3 months. Without glucocorticoid supplementation, her hypercalcemia was normalized. After the normalization, she was diagnosed as having isolated ACTH deficiency. Strachan et al reported on a 45 -year-old male who presented with

Table I Endocrinological findings. Basal endocrinological value and responses of pituitary hormones to intravenous injection of I $00 \mu \mathrm{g}$ corticotropin-releasing hormone, $100 \mu \mathrm{g}$ growth hormone $(\mathrm{GH})$-releasing factor, $100 \mu \mathrm{g}$ luteinizing hormone (LH)-releasing hormone, and $200 \mu \mathrm{g}$ thyrotropin-releasing hormone

\begin{tabular}{|c|c|c|c|c|c|c|}
\hline Time & $0 \mathrm{~min}$ & $30 \mathrm{~min}$ & $60 \mathrm{~min}$ & $90 \mathrm{~min}$ & $120 \mathrm{~min}$ & NR \\
\hline $\mathrm{ACTH}(\mathrm{pg} / \mathrm{dL})$ & $<1.0$ & $<1.0$ & $<1.0$ & $<1.0$ & $<1.0$ & $7.2-63.3$ \\
\hline Serum cortisol $(\mu g / d L)$ & 0.278 & 0.23 & 0.22 & 0.20 & 0.20 & $6.20-19.4$ \\
\hline $\mathrm{TSH}(\mu \mathrm{IU} / \mathrm{mL})$ & 0.492 & 7.940 & 6.28 & 4.840 & 3.410 & $0.45-4.95$ \\
\hline $\mathrm{FSH}(\mathrm{mlU} / \mathrm{mL})$ & 61.02 & 69.01 & 77.55 & 79.41 & 84.89 & $5.72-64.3$ \\
\hline $\mathrm{LH}(\mathrm{mlU} / \mathrm{mL})$ & 32.26 & 76.05 & 84.38 & 84.58 & 80.02 & $<157.8$ \\
\hline PRL (ng/mL) & 27.29 & 133.55 & 92.23 & 68.13 & 51.65 & $6.12-30.5$ \\
\hline $\mathrm{GH}(\mathrm{ng} / \mathrm{mL})$ & 2.643 & 27.73 & 41.18 & 29.03 & 14.38 & $0.01-3.61$ \\
\hline Somatomedin C (ng/mL) & 124 & & & & & $48-177$ \\
\hline
\end{tabular}

Abbreviations: ACTH, adrenocorticotropic hormone; FSH, follicle-stimulating hormone; GH, growth hormone; LH, luteinizing hormone; min, minutes; NR, normal reference; PRL, prolactin; TSH, thyroid-stimulating hormone. 
Table 2 Insulin tolerance test

\begin{tabular}{lllllll}
\hline Time & $\mathbf{0}$ min & $\mathbf{3 0} \mathbf{~}$ in & $\mathbf{6 0} \mathbf{~}$ in & $\mathbf{9 0} \mathbf{~ m i n}$ & $\mathbf{1 2 0} \mathbf{~ m i n}$ & $\mathbf{N R}$ \\
\hline Glucose $(\mathrm{mg} / \mathrm{dL})$ & 70 & 41 & 66 & 69 & 71 & $80-110$ \\
ACTH $(\mathrm{pg} / \mathrm{dL})$ & $<1.0$ & $<1.0$ & $<1.0$ & $<1.0$ & $<1.0$ & $7.2-63.3$ \\
Serum cortisol $(\mu \mathrm{gg} / \mathrm{dL})$ & 0.273 & 0.28 & 0.35 & 0.27 & 0.22 & $6.20-19.4$ \\
$\mathrm{GH}(\mathrm{ng} / \mathrm{mL})$ & 0.43 & 0.242 & 5.176 & 4.804 & 3.606 & $0.01-3.61$ \\
\hline
\end{tabular}

Abbreviations: $\mathrm{ACTH}$, adrenocorticotropic hormone; $\mathrm{GH}$, growth hormone; min, minutes; NR, normal reference.

altered consciousness due to severe hypercalcemia (total serum calcium $3.56 \mathrm{mmol} / \mathrm{L}$, albumin $35 \mathrm{~g} / \mathrm{L}) .{ }^{10}$ Initially, he was diagnosed as having hyperthyroidism. After extensive investigations, he also had isolated ACTH deficiency. Glucocorticoid administration resulted in dramatic improvement of his clinical state and serum calcium level.

In this case, regarding symptoms, appetite loss that was too severe for mild hypercalcemia and refractory epigastric pain without remarkable endoscopic gastrointestinal abnormalities were important clues to suspect metabolic or endocrine diseases. With regard to laboratory findings, except for the hypercalcemia, electrolyte abnormalities were very trivial. Compared with past case reports, the severity of hypercalcemia was so mild that it is quite reasonable to consider dehydration as the cause. It was a pitfall to make the diagnosis challenging. In a case of hypercalcemia unresponsive to fluid replacement, we recommend ruling out adrenocortical insuf-

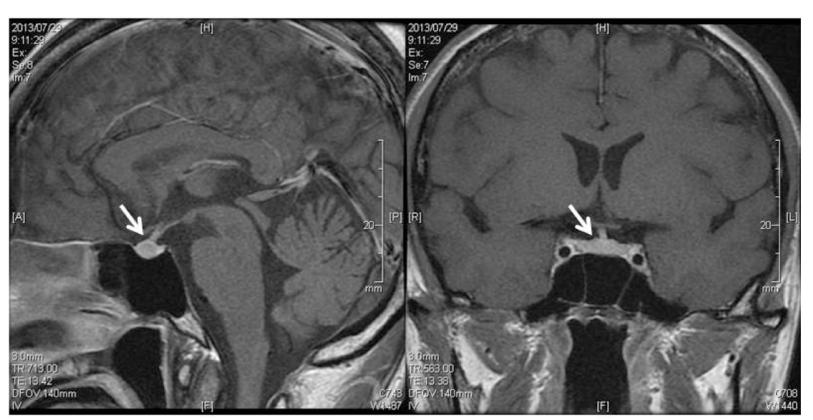

Figure I Gadlinium-enhanced pituitary MRI (TI-weighted images).

Note: These images showed no enlargement of the pituitary gland or enhancing effect abnormality (white arrow).

Abbreviation: MRI, magnetic resonance imaging. ficiency including isolated ACTH deficiency after excluding more common diseases: malignancy, hyperparathyroidism, hyperthyroidism, and vitamin D intoxication.

\section{Disclosure}

The authors report no conflicts of interest in this work.

\section{References}

1. Nerup J. Addison's disease-clinical studies: A report for 108 cases. Acta Endocrinol (Copenh). 1974;76(1):127-141.

2. Andrioli M, Pecori Giraldi F, Cavagnini F. Isolated corticotrophin deficiency. Pituitary. 2006;9(4):289-295.

3. Hannon MJ, O'Halloran DJ. Isolated acquired ACTH deficiency and primary hypothyroidism: a short series and review. Pituitary. 2011;14(4):358-361.

4. Hirao K, Kikawada M, Otoguro M, et al. [Elderly case of isolated ACTH deficiency presenting with depression and digestive symptoms]. Nihon Ronen Igakkai Zasshi. 2007;44(1):117-121. Japanese.

5. Odagaki T, Noguchi Y, Fukui T. Flexion contractures of the legs as the initial manifestation of adrenocortical insufficiency. Intern Med. 2003;42(8):710-713.

6. Sakihara S, Kageyama K, Nigawara T, Kidani Y, Suda T. Ampulla (Takotsubo) cardiomyopathy caused by secondary adrenal insufficiency in ACTH isolated deficiency. Endocr J. 2007;54(4):631-636.

7. Ukita C, Miyazaki H, Toyoda N, Kosaki A, Nishikawa M, Iwasaka T. Takotsubo cardiomyopathy during acute adrenal crisis due to isolated adrenocorticotropin deficiency. Intern Med. 2009;48(5):347-352.

8. Grossmann M, Fuller P, Hunter A, Teede H. Isolated ACTH deficiency presenting with hypercalcaemia. Clin Endocrinol (Oxf). 2007;66(4):603-604.

9. Kato A, Shinozaki S, Goga T, Hishida A. Isolated adrenocorticotropic hormone deficiency presenting with hypercalcemia in a patient on long-term hemodialysis. Am J Kidney Dis. 2003;42(2):E32-E36.

10. Strachan MW, Walker JD, Patrick AW. Severe hypercalcaemia secondary to isolated adrenocorticotrophic hormone deficiency and subacute thyroiditis. Ann Clin Biochem. 2003;40(Pt 3):295-297.
International Medical Case Reports Journal

\section{Publish your work in this journal}

The International Medical Case Reports Journal is an international, peer-reviewed open-access journal publishing original case reports from all medical specialties. Previously unpublished medical posters are also accepted relating to any area of clinical or preclinical science. Submissions should not normally exceed 2,000 words or

\section{Dovepress}

4 published pages including figures, diagrams and references. The manuscript management system is completely online and includes a very quick and fair peer-review system, which is all easy to use. Visit http://www.dovepress.com/testimonials.php to read real quotes from published authors. 